\title{
Sebaceous gland hyperplasia of vulva: A case report
}

\author{
Vulvanın sebasöz bezlerinin hiperplazisi: Olgu sunumu
}

\author{
Erhan Yavuz*a , Handan Celik ${ }^{\mathrm{b}}$, Arif Kokcu' ${ }^{\mathrm{b}}$, Yurdanur Süllü̈
}

${ }^{a}$ Fatsa State Hospital, Ordu, Turkey

${ }^{b}$ Department of Obstetrics and Gynecology, School of Medicine, Ondokuz Mayis University, Samsun, Turkey

${ }^{c}$ Department of Pathology, School of Medicine, Ondokuz Mayis University, Samsun, Turkey

\begin{tabular}{|c|c|c|}
\hline \multicolumn{2}{|c|}{ ARTICLE INFO } & \multirow{2}{*}{$\begin{array}{l}\text { ABSTRACT } \\
\text { Sebaceous gland hyperplasia is a cutaneous lesion occurring on the face in elderly patients. }\end{array}$} \\
\hline Article $\mathbf{H}$ & & \\
\hline Received & $26 / 01 / 2012$ & The occurrence of the lesion on the vulva is exceptionally rare. We have identified only \\
\hline Accepted & $03 / 02 / 2012$ & six cases reported in the literature so far. Vulvar lesions were predominantly on the labia \\
\hline \multicolumn{2}{|c|}{ * Correspondence to: } & regions, that the cases of vulvar sebaceous gland hyperplasia were seen predominantly \\
\hline \multicolumn{2}{|c|}{ Erhan Yavuz } & in women of reproductive age and that they were in the greater dimensions were two \\
\hline \multicolumn{2}{|c|}{ Evkaf Mahallesi, } & interesting peculiarities of these lesions. We here in report a new case of sebaceous gland \\
\hline \multicolumn{2}{|c|}{ Fatsa Devlet Hastanesi, } & $\begin{array}{l}\text { hyperplasia in the right labium minus of vulva. } \\
\text { J. Exp. Clin. Med., 2012; 29:231-233 }\end{array}$ \\
\hline
\end{tabular}

Fatsa/Ordu, Turkey

e-mail:yavuzerhan.g@gmail.com

\section{ÖZET}

\section{Keywords:}

Sebaceous gland hyperplasia

Vulvar polypoid lesions

Sebaceous glands

Vulva
Sebasöz bez hiperplazisi, yaşlı hastalarda yüzde meydana gelen bir cilt lezyonudur. Lezyonun vulvada ortaya çıkması son derece nadirdir. Literatürde şimdiye kadar sadece 6 olgu tanımlanmıştır. Vulvar lezyonlar genelde labia minorada ve polipoidal görünümdedir. Yüzdeki ve diğer bölgelerdeki lezyonlara karşıllk vulvar lezyonların iki ilginç özelliği, genelde reprodüktif dönemdeki kadınlarda gözlenmiş ve daha büyük boyutlara ulaşmış olmalarıdır. Biz bu olgu sunumunda vulvada sağ labium minorada sebasöz bez hiperplazili yeni bir olgu bildirdik.

J. Exp. Clin. Med., 2012; 29:231-233

\footnotetext{
Anahtar Kelimeler:

Sebasöz bez hiperplazisi

Vulvar polipoid lezyonlar

Sebasöz bezler

Vulva
}

\section{Introduction}

Sebaceous gland hyperplasia consists of multiple asymptomatic small yellow papules with a central depression, occurring most commonly on the forehead and cheeks, but occasionally affecting the areola, chest or genital skin. These lesions are sometimes clinically mistaken for basal-cell carcinoma. Sebaceous gland hyperplasia is now considered as a hamartoma rather than a true neoplasm. Sebaceous gland hyperplasia has been defined as the presence of $>4$ sebaceous lobules attached to the infundibulum of each pilosebaceous unit (Al-Daraji et al., 2007). Sebaceous gland hyperplasia of the vulva is ex- ceedingly rare. We searched the PubMed Medline database for previous case reports using the key words "vulva" and " sebaceous hyperplasia ". We found only six cases reported in the literature so far. In this article, we report a new case of sebaceous gland hyperplasia of the vulva.

\section{Case}

A 36-year-old woman presented to the gynecology outpatients clinic with complaints of severe pruritus and burning on the right side of the vaginal orifice for two months. She had noticed a swelling on her right labium minus a month 
ago. She was not married, had not had any sexual intercourse and was virgin. She had no other medical history. She had regular menstrual cycles (for 6-7 days, each 26-30 days), and menarche was at the age of 12 . On physical examination, secondary sex characteristics were normal, and hirsutismus was not present. On gynecological examination, four polypoidal masses in sizes of 10x10 mm were seen on medial surface of her right labium minus. These polypoidal masses were mildly tender with palpation and covered by normal appearing skin. Pelvic ultrasound did not show any pathological finding. The lesions were removed by local excision under local anaesthesia. Histopathological examination revealed enlarged sebaceous gland composed of numerous lobules grouped around a centrally located sebaceous duct. Most of the sebaceous gland lobules appeared mature (Fig. 1A). The cells had vesiculated cytoplasm and central nucleus with no atypical features (Fig. 1B). Overlying epidermis didn't have any pathological feature. Immunohistochemical staining showed positivity for epithelial membrane antigen (EMA), (Neomarkers, 1:200) (Fig. 1C). A diagnosis of sebaceous gland hyperplasia was made. Immunoreactivity for estrogen, progesteron receptors and prolactin were not observed. Since the sebaceous glands are known to contain androgen receptors, however, we have not examined these receptors.

\section{Discussion}

Sebaceous glands are distributed over most of the skin surface associated with hair follicles, and they may also open directly to the epithelial surface in certain locations such as eyelids (Meibomiam glands), mammary areolae (Montgomery's glands), labia minora and glans (Tyson's glands), and lips/ buccal mucosa (Fordyce's spots) (Ortiz-Rey et al., 2002). Sebaceous glands are well-developed a few weeks after birth, most likely because of maternal hormones. After a few months, they undergo considerable atrophy and are almost undetectable during childhood. At puberty, as a result of increased androgen output, the sebaceous glands become greatly enlarged and reach their maximum sizes at the third decade of life; they remain constant until middle age, and tend to decrease slowly at the seventh decade. Androgen receptors are present in normal skin, being localized to the basal and differentiating cells of the sebaceous gland, and sebaceous glands are therefore androgen sensitive and their secretions are controlled by androgen expression (Bakaris et al., 2004).

Aged facial sebaceous glands undergo hypertrophy due to a decrease in cellular turnover secondary to reduced androgen levels, leading to an increase in the size of the glands. However, this does not explain the hyperplasia that occurs in the glands of the vulva.

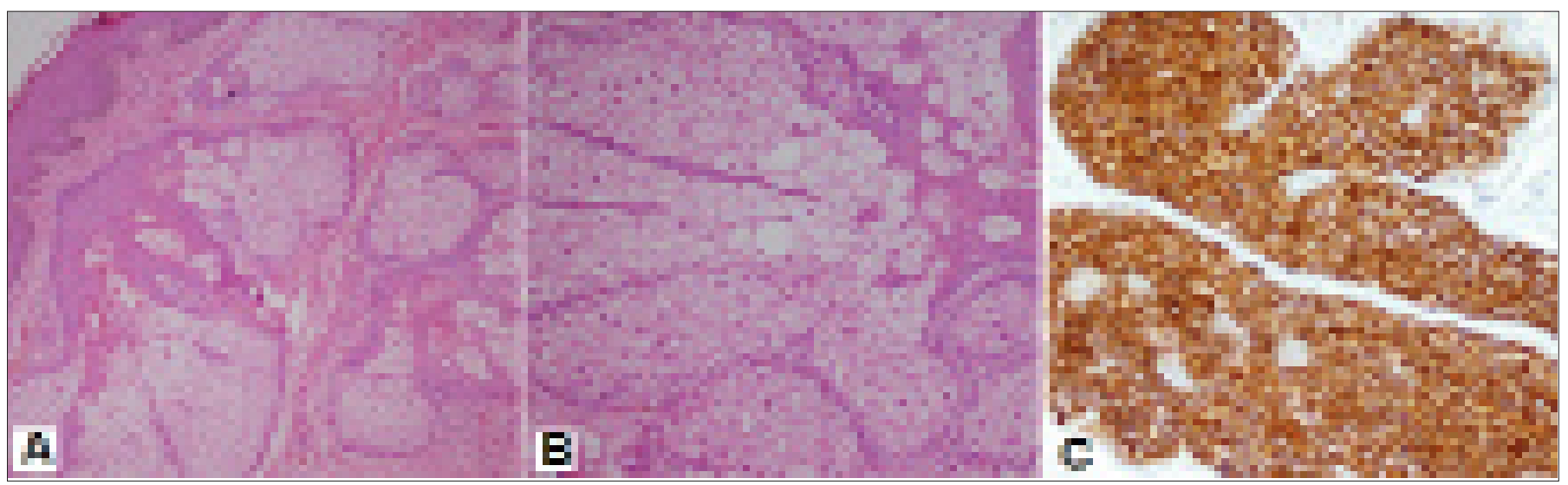

Fig. 1. A. Enlarged sebaceous gland with branching duct in the center, HE, x100; B and C: Sebaceous cells with vesiculated cytoplasm and central nuclei without atypia, HE, x200 (B); EMA, x200 (C).

Table 1. The reported cases of vulvar sebaceous gland hyperplasia

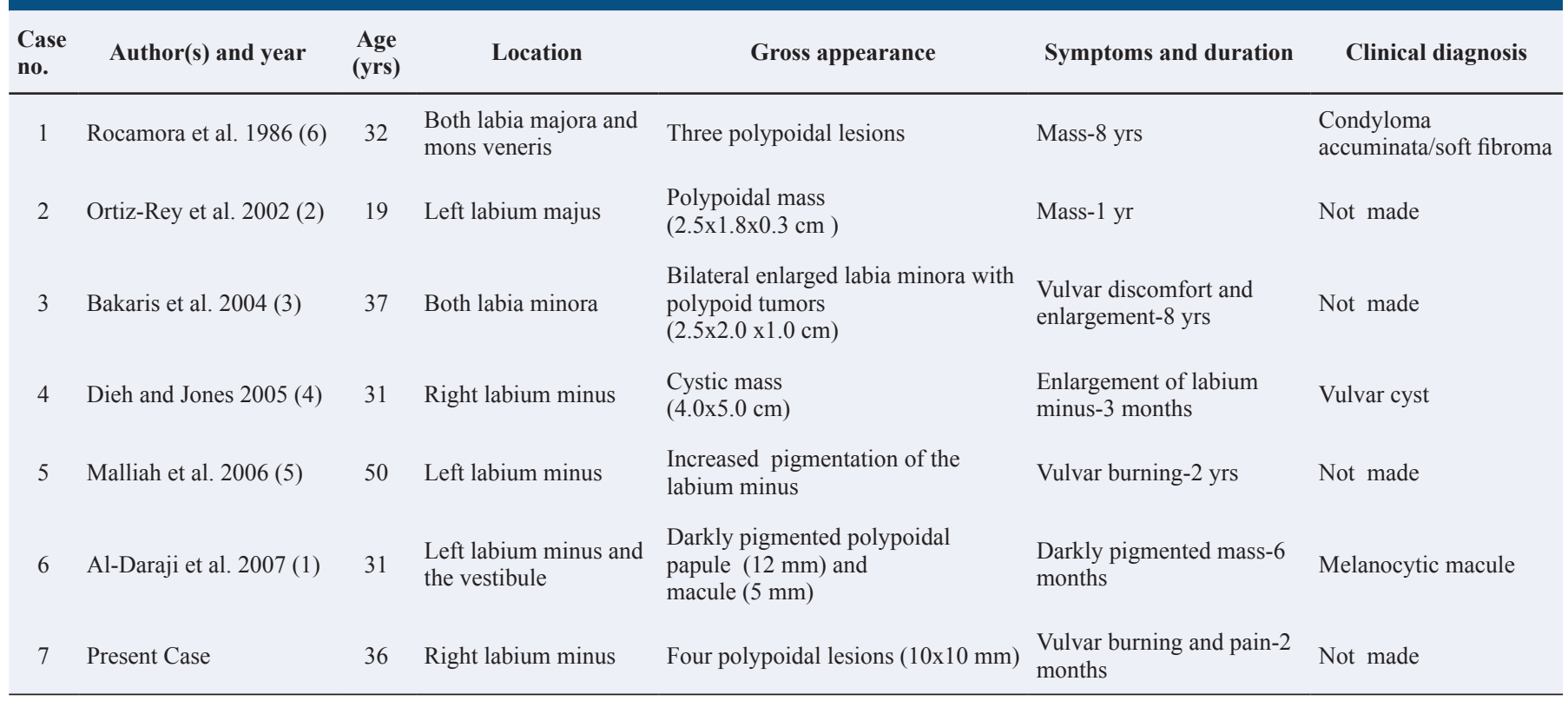


Contrary to the facial lesions, the reported cases of vulvar sebaceous gland hyperplasia were seen in women of reproductive age. The reason for this preponderance is probably due to a higher sensitivity of the cells to androgen (Dieh and Jones, 2005). Sebaceous gland hyperplasia is a common, benign usually facial condition of sebaceous glands in adults past middle age. Lesions can be solitary or multiple and usually consist of 1 to $3 \mathrm{~mm}$, yellowish, soft, umbilicated, papules on the face, especially the cheeks, nose, and forehead. Sebaceous gland hyperplasia also occasionally occurs on the chest skin, mammary areola, mouth, and penis. Lesions of sebaceous hyperplasia are benign, with no known potential for malignant progression. Sebaceous gland hyperplasia consists of hamartomatous idiopathic enlargement of individual sebaceous glands (Malliah et al., 2006).

Sebaceous gland hyperplasia of the vulva is exceedingly rare, and only six cases have been reported in the literature (Rocamora et al., 1986; Ortiz-Rey et al., 2002; Bakaris et al., 2004; Dieh and Jones, 2005; Malliah et al., 2006; Al-Daraji et al., 2007). Table 1 shows the previous six and the present case. The age range of the reported cases was between 19 and 50 (mean 33.3) years. Cases with vulvar sebaceous gland hyperplasia were seen to be at young age compared with a mean age of 61.2 years reported in some series of sebaceous hyperplasia of the face (Al-Daraji et al., 2007). The gross appearance of the lesions on the vulva was single or multiple polypoid lesions or pigmented lesions of the vulva ranging in size from 1 to $5 \mathrm{~cm}$ in greatest dimension (Malliah et al., 2006). The present case had four polypoidal masses in sizes of $10 \times 10 \mathrm{~mm}$ on medial surface of her right labium minus and she complained about vulvar pruritus and burning. Histopathological examination revealed that the specimens contained numerous hyperplastic lobules of mature sebaceous glands surrounding a centrally dilated duct. The lipid-laden sebaceous cells were fully matured, consistent with benign hyperplasia of sebaceous gland (Fig. 1 A, B and C). Histopathological diagnosis was sebaceous gland hyperplasia. Moreover, it has been seen that these patients did not have a specific symptom. That all these seven cases (including our case) could not be diagnosed clinically might be explained with this pathologic situation's being seen very rarely (Table 1).

The clinical and gross differential diagnosis includes basal cell carcinoma, acrochordon, condyloma acuminata, molluscum contagiosum, angiofibroma, intradermal nevus, and xanthoma. Besides, it is important to note the differential diagnosis for pigmented vulvar lesions includes vulvar melanosis, pigmented nevi, and melanoma. Malignant melanoma is the second most common malignant tumor of the vulva, and $30 \%$ occur in women younger than 50 ; hence, this must always be considered when evaluating a pigmented lesion (Malliah et al., 2006). Histologic differential diagnosis must be carried out with other lesions composed mostly of mature sebaceous cells such as nevus sebaceous of Jadassohn, sebaceous adenoma, folliculosebaceous cystic hamartoma/sebaceous trichofolliculoma, and sebaceoma (Ortiz-Rey et al., 2002).

It is also important to biopsy any unusual-looking lesions in the vulva to exclude the possibility of intraepithelial neoplasia and malignancy (Al-Daraji et al., 2007). Treatment of the lesions is usually for cosmetic reasons but larger lesions such as those on the vulva could cause discomfort and require excision. Although other forms of treatment for sebaceous gland hyperplasia have been described, such as topical medication, electrocautery, cryocautery and laser therapy, excision was deemed for the appropriate management in this case due to its size and anatomical site (Dieh and Jones, 2005).

In conclusion, this clinical entity is very rare and only six patients with vulvar sebaceous gland hyperplasia have been reported up to date. It was seen that these vulvar lesions were predominantly on the labia minora and polipoidal in appearance. Besides, contrary to the lesions on the face and the other regions, that the cases of vulvar sebaceous gland hyperplasia were seen predominantly in women of reproductive age and that they were in the greater dimensions were two interesting peculiarities of these lesions. To the best of our knowledge, the present case is the seventh case of vulvar sebaceous gland hyperplasia.

\section{REFERENCES}

Al-Daraji, W.I., Wagner, B., Ali, R.B., McDonagh, A.J., 2007. Sebaceous hyperplasia of the vulva: A clinicopathological case report with a review of the literature. J. Clin. Pathol. 60, 835-837.

Bakaris, S., Kiran, H., Kiran, G., 2004. Sebaceous gland hyperplasia of the vulva. Aust. N.Z.J. Obstet. Gynaecol. 44, 75-76.

Dieh, A.P.T., Jones, A.S., 2005. An unusual presentation of sebaceous gland hyperplasia of the vulva. J. Obstet. Gynaecol. 25, 729-730.

Malliah, R., Gilhooly, P., Lambert, W.C., Heler, D.S., 2006. Sebaceous hyperplasia of the vulva: Case report and review of the literature. J. Low. Genit. Tract Di. 10, 55-57.

Ortiz-Rey, J.A., Martín-Jiménez, A., Alvarez, C., De La Fuente, A., 2002. Sebaceous gland hyperplasia of the vulva. Obstet. Gynecol. 99, 919921.

Rocamora, A., Santonja, C., Vives, R., Varona, C., 1986. Sebaceous gland hyperplasia of the vulva: A case report. Obstet. Gynecol. 68, 63-65. 